\title{
PROSES UNTUK MEMPEROLEH PERLINDUNGAN HAK PATEN DI INDONESIA
}

Erwin Gustiawan

155100096

Fakultas Komputer, 448757226

erwingustiawan.student@umitra.ac.id

\begin{abstract}
Paten menganut prinsip teritorial, yang artinya perlindungan paten hanya berlaku di negara di mana permohonan paten diajukan dan diberi. Untuk memperoleh perlindungan paten di wilayah hukum Indonesia, maka sang inventor harus mengajukan permohonan paten di Indonesia, dalam hal ini ke Direktorat Jenderal Hak Kekayaan Intelektual (DJHKI). Di sisi lain inventor yang hanya mematenkan invensinya di Indonesia, tidak memiliki hak paten di negara lain.

Di sisi lain, hal ini berarti kita bebas untuk memanfaatkan invensi yang dipatenkan di luar negeri namun tidak di Indonesia, bahkan untuk memproduksinya secara komersial, sepanjang kita tidak mengekspor produk tersebut ke negara di mana invensi itu dipatenkan; dan demikian pula sebaliknya terhadap invensi-invensi yang hanya dipatenkan di Indonesia.
\end{abstract}

Kata Kunci : Proses Hak Paten 


\section{A. INTRODUCTION}

1. Pengertian paten

Paten adalah hak eksklusif yang diberikan oleh Negara kepada penemu atas hasil penemuannya di bidang teknologi, yang untuk selama waktu tertentu melaksanakan sendiri Invensinya tersebut atau memberikan persetujuannya kepada pihak lain untuk melaksanakannya. (UU RI no. 14 tahun 2001, ps. 1, ay. 1)

Sementara itu, arti Invensi dan Inventor (yang terdapat dalam pengertian di atas, juga menurut undang-undang tersebut, adalah):

- Invensi adalah ide Inventor yang dituangkan ke dalam suatu kegiatan pemecahan masalah yang spesifik di bidang teknologi dapat berupa produk atau proses, atau penyempurnaan dan pengembangan produk atau proses. (UU RI no. 14 tahun 2001, ps. 1, ay. 2)

- Inventor adalah seorang yang secara sendiri atau beberapa orang yang secara bersama-sama melaksanakan ide yang dituangkan ke dalam kegiatan yang menghasilkan Invensi. (UU RI no. 14 tahun 2001, ps. 1, ay. 3)

Kata paten, berasal dari bahasa inggris patent, yang awalnya berasal dari kata patere yang berarti membuka diri (untuk pemeriksaan publik), dan juga berasal dari istilah letters patent, yaitu surat keputusan yang dikeluarkan kerajaan yang memberikan hak eksklusif kepada individu dan pelaku bisnis tertentu. Dari definisi kata paten itu sendiri, konsep paten mendorong inventor untuk membuka pengetahuan demi kemajuan 
masyarakat dan sebagai gantinya, inventor mendapat hak eksklusif selama periode tertentu. Mengingat pemberian paten tidak mengatur siapa yang harus melakukan invensi yang dipatenkan, sistem paten tidak dianggap sebagai hak monopoli.

\section{Waktu paten}

Dalam paten berlaku prinsip first to file, di mana hak paten hanya akan diberikan kepada yang pertama kali mengajukan permohonan paten yang setidaknya sudah dilengkapi syarat minimum pengajuannya, sehingga berhak

mendapatkan Tanggal

Penerimaan (filing

date). Dengan demikian, paten bersifat sangat timesensitive sehingga waktu pengajuan permohonan menjadi faktor yang sangat krusial. Konon dalam sejarah, Alexander Graham

Bell diakui sebagai inventor telefon hanya karena ia mengajukan permohonan paten setengah jam lebih awal daripada kompetitornya.

Apalagi syarat
substantif paten dari
sisi kebaruan

(novelty) membuat suatu invensi tidak akan dapat dipatenkan manakala invensi tersebut sudah terlanjur terungkap ke publik sebelum Tanggal Penerimaanpermohonanny a. Dengan demikian, wajar kiranya jika banyak orang/lembaga/perusahaan yang memilih untuk secepatnya mengajukan permohonan paten atas invensi mereka, meskipun mereka belum sungguhsungguh memastikan apakah invensi tersebut memiliki nilai komersial. Bagi banyak pihak, biaya pendaftaran paten yang 


\author{
terbuang untuk sejumlah \\ invensi yang tidak \\ komersial tidaklah seberapa \\ dibandingkan kerugian \\ tidak memilki hak paten \\ atas satu invensi yang \\ bernilai komersial tinggi.
}
3. Proses Pengajuan Hak Patean

Sebelum mengajukan permohonan paten, sangat disarankan agar inventor terlebih dahulu melaksanakan penelusuran (search), untuk memperoleh gambaran apakah invensi yang diajukan memang memenuhi syarat kebaruan, artinya belum pernah ada pengungkapan sebelumnya oleh siapapun, termasuk oleh si inventor sendiri. Penelusuran dapat dilakukan terhadap dokumen-dokumen paten baik yang tersimpan pada database DJHKI, maupun kantor-kantor paten lain di luar negeri yang representatif dan juga relevan terhadap teknologi dari invensi yang akan kita patenkan; dan juga terhada dokumendokumen non-paten seperti jurnal-jurnal ilmiah yang terkait.

Penelusuran Paten bahkan sangat disarankan untuk dilakukan sebelum rencana penelitian terhadap suatu teknologi dilaksanakan, demi untuk melakukan technology mapping berdasarkan dokumen paten yang tersedia, sehingga penelitian bisa dilakukan secara lebih efektif dan efisien. Setelah dilakukan penelusuran dan dapat diyakini bahwa invensi yang akan dipatenkan masih mengandung kebaruan, langkah selanjutnya adalah membuat spesifikasi paten, yang terdiri sekurangkurangnya atas:

- Judul Invensi;

- Latar Belakang Invensi, yang menerangkan teknologi yang ada sebelumnya serta masalah yang terdapat pada teknologi tersebut, 
yang coba

ditanggulangi oleh

invensi;

- Uraian Singkat Invensi, yang menerangkan secara ringkas mengenai fitur-fitur yang terkandung dalam, dan menyusun, invensi;

- Uraian Lengkap Invensi, $\quad$ yang menerangkan mengenai bagaimana cara melaksanakan invensi;

- Gambar Teknik, jika diperlukan untuk menerangkan invensi secara lebih jelas;

- Uraian Singkat

Gambar, untuk menerangkan mengenai Gambar Teknik yang disertakan;

- Abstrak, ringkasan mengenai invensi dalam satu atau dua paragraf;

- Klaim, yang memberi batasan mengenai fiturfitur apa saja yang dinyatakan sebagai baru dan inventif oleh sang inventor, sehingga layak mendapatkan hak paten.

Penyusunan spesifikasi paten membutuhkan keahlian dan pengalaman tersendiri, karena perlu memadukan antara bahasa teknik dan bahasa hukum di dalamnya. Banyak Konsultan HKI Terdaftar yang memiliki kualifikasi keahlian dan pengalaman tersebut, serta akan dapat membantu Anda dalam menyusun Spesifikasi Invensi.

Spesifikasi Paten adalah salahsatu dari persyaratan minimum yang harus disertakan dalam mengajukan permohonan paten untuk bisa mendapat Tanggal Penerimaan, di samping Formulir Permohonan yang diisi lengkap dan dibuat rangkap empat, dan membayar biaya Permohonan Paten sebesar Rp. 750.000,00. Apabila ketiga persyaratan minimum ini dipenuhi, maka 
permohonan akan mendapat

Tanggal Penerimaan (Filing

Date).

Persyaratan lain berupa persyaratan formalitas dapat dilengkapi selama tiga bulan sejak Tanggal Penerimaan, dan dapat dua kali diperpanjang, masing-masing untuk dua dan satu bulan. Persyaratan formalitas tersebut adalah:

- Surat Pernyataan Hak, yang merupakan pernyataan Pemohon Paten bahwa ia memang memiliki hak untuk mengajukan permohonan paten tersebut;

- Surat Pengalihan Hak, yang merupakan bukti pengalihan hak dari Inventor kepada Pemohon Paten, jika Inventor dan Pemohon bukan orang yang sama;
- Surat Kuasa, jika permohonan diajukan melalui Kuasa;

- Fotokopi KTP/Identitas Pemohon, jika Pemohon perorangan;

- Fotokopi Akta

Pendirian Badan Hukum yang telah dilegalisir, jika Pemohon adalah Badan Hukum;

- Fotokopi NPWP Badan Hukum, jika Pemohon adalah Badan Hukum; dan

- Fotokopi KTP/Identitas orang yang bertindak atas nama Pemohon Badan Hukum untuk menandatangani Surat Pernyataan dan Surat Kuasa.

Setelah masa pemeriksaan dilalui dan seluruh persyaratan formalitas dinyatakan lengkap, maka tahap berikutnya adalah Pengumuman. Masa pengumuman akan dimulai 


segera setelah 18
(delapanbelas) bulan berlalu
dari sejak Tanggal Penerimaan,
dan akan berlangsung selama 6
(enam) bulan. Memasuki masa
pengumuman ini permohonan
paten akan dimuat dalam Berita
Resmi Paten dan media resmi
pengumuman paten lainnya.
Tujuannya adalah membuka
kesempatan kepada masyarakat
untuk mengetahui mengenai
invensi yang dimohonkan
paten, di mana masyarakat bisa
mengajukan keberatan secara
tertulis kepada DJHKI jika
masyarakat mengetahui bahwa
invensi tersebut tidak
memenuhi syarat untuk
dipatenkan.

\section{B. CONCLUSION}

Kesimpulan :

Setelah dilakukan penelusuran dan dapat diyakini bahwa invensi yang akan dipatenkan masih mengandung kebaruan, langkah selanjutnya adalah membuat spesifikasi paten, yang terdiri sekurang-kurangnya atas:

- Judul Invensi;

- Latar Belakang Invensi, yang menerangkan teknologi yang ada sebelumnya serta masalah yang terdapat pada teknologi tersebut, yang coba ditanggulangi oleh invensi;

- Uraian Singkat Invensi, yang menerangkan secara ringkas mengenai fitur-fitur yang terkandung dalam, dan menyusun, invensi;

- Uraian Lengkap Invensi, yang menerangkan mengenai bagaimana cara melaksanakan invensi;

- Gambar Teknik, jika diperlukan untuk menerangkan invensi secara lebih jelas;

- Uraian Singkat Gambar, untuk menerangkan mengenai Gambar Teknik yang disertakan; 
- Abstrak, ringkasan

mengenai invensi dalam

satu atau dua paragraf;

- Klaim, yang memberi batasan mengenai fitur-fitur apa saja yang dinyatakan sebagai baru dan inventif oleh sang inventor, sehingga layak mendapatkan hak paten.

\section{ACKNOWLEDGEMENT}

University Of Indonesia

University Of Mitra Indonesia

Telkom University

University Of Mellbourne

Saitama University 


\section{REFERENCE (Based ISO 690 )}

A. S. Putra And O. M. Febriani, "Knowledge Management Online Application In Pdam Lampung Province," In Prosiding International Conference On Information Technology And Business (Icitb), 2018, Pp. 181-187.

[2] A. S. Putra, O. M. Febriani, And B. Bachry, "Implementasi Genetic Fuzzy System Untuk Mengidentifikasi Hasil Curian Kendaraan Bermotor Di Polda Lampung," J. Sist. Inf. Dan Manaj. Basis Data, Vol. 1, No. 1, Pp. 21-30, 2018.

[3] O. M. Febriani And A. S. Putra, "Sistem Informasi Monitoring Inventori Barang Pada Balai Riset Standardisasi Industri Bandar Lampung," J. Inform., Vol. 13, No. 1, Pp. 90-98, 2014.

[4] Putra, Arie Setya. "2018 Artikel Struktur Data, Audit Dan Jaringan Komputer." (2018).

[5] Putra, A. S. (2018, July 17). Paperplain Fundamental Create Application With Borland Delphi 7.0 University Of Mitra Indonesia. Retrieved From Osf.Io/Pbrn9.

\section{E. REFERENCE (Based APA)}

Putra, A. S., Aryanti, D. R., \& Hartati, I. (2018, November). Metode SAW (Simple Additive Weighting) sebagai Sistem Pendukung Keputusan Guru Berprestasi (Studi Kasus: SMK Global Surya). In Prosiding Seminar Nasional Darmajaya (Vol. 1, No. 1, pp. 85-97).

Sari, D. P., Febriani, O. M., \& Putra, A. S. (2018, November). Perancangan Sistem Informasi SDM Berprestasi pada SD Global Surya. In Prosiding Seminar Nasional Darmajaya (Vol. 1, No. 1, pp. 289-294).

Putra, A. S. (2018). Paperplain: Execution Fundamental Create Application With Borland Delphi 7.0 University Of Mitra Indonesia.

Putra, A. S., Sukri, H., \& Zuhri, K. Sistem Monitoring Realtime Jaringan Irigasi Desa (JIDES) Dengan Konsep Jaringan Sensor Nirkabel. IJEIS (Indonesian Journal of Electronics and Instrumentation Systems), 8(2), 221232.

Darmawan, A., Yuliawati, D., Marcella, O., \& Firmandala, R. (2016). Sistem Absensi dan Pelaporan Berbasis Fingerprint dan SMS Gateway. EXPLORE, 7(1). 
Febriani, O. M., Wahyuni, T., \& Yusuf, S. (2017). DESIGN OF WEBSITE-BASED INFORMATION SYSTEM FOR EDOCUMENT

ADMINISTRASI IN THE
COMMUNITY SERVICE UNIT (A Case Study at Rajabasa District). INTERNATIONAL JOURNAL OF COMPUTERS \& TECHNOLOGY, 16(7), 7010-7020.

Febriani, O. M., \& Wahyuni, T. (2017, October). PERANCANGAN SISTEM E-DOCUMENT ADMINISTRASI LOGBOOK PENELITIAN PADA UNIT LAYANAN DI BANDAR LAMPUNG. In Prosiding Seminar Nasional Darmajaya (Vol. 1, No. 1, pp. 187-194).

Febriani, O. M., \& Permadi, A. B. (2017). Implementasi Sistem Aplikasi Data Bimbingan dan Pelanggaran Siswa pada Sekolah Menengah Atas di Lampung Tengah dengan Metode Analisis dan Desain Sistem Terdistribusi (SSAD). EXPERT, 7(1).

Febriani, O. M., \& Ambarwati, L. (2015). PERANCANGAN APLIKASI PENGOLAHAN DATA PENJUALAN UKM KELANTING KHAS TELO DESA SIDOHARJO KECAMATAN JATI AGUNG KABUPATEN LAMPUNG SELATAN. Jurnal Teknologi Informasi dan Bisnis Pengabdian Masyarakat Darmajaya, 1(1), 77-95.

Febriani, O. M. (2015). Rancang Bangun Aplikasi Ecommercemenggunakan Freewebstore pada UKM Kelanting di Desa Sidoharjo Lampung Selatan. Prosiding Sembistek 2014, 1(02), 446-458. 